\title{
ANALYSIS OF INTERNATIONAL TOURIST FLOWS BETWEEN UKRAINE AND SLOVAKIA
}

\author{
Oresta Bordun
}

\begin{abstract}
The modern state of international Ukraino-Slovakian tourist flows disclosed in the article. There are several factors that determined the current state tourist flows between Ukraine and Slovakia: historical, geographical, ethnic, and social development of transport infrastructure. The coefficient of tourist exchanges between Ukraine and Slovak Republic identified for the help of the statistical sources from the State Border Service in Ukraine. Major trends formation of tourist flows in Ukraine and Slovak Republic in period of 2009-2013 are analysed. Detected the main reasons predominance of tourist flows from Ukraine to Slovak Republic. The most important tourist resources of Ukraine, which could attract Slovak tourists briefly described.
\end{abstract}

Keywords: international travel, inbound tourism, outbound tourism, tourist flows

\section{Introduction}

The aim of this publication are coverage of geospatial particular arrangement and dynamic of tourist flows between Ukraine and Slovak Republic, which due to profitable geographic location and transport availability, have many common things, particular, in development of tourism section; also factors, which affected on development of international tourism first of all.

Research of problem and prospects formation and development international tourist exchange between Ukraine and Slovak Republic requires solution follow tasks:

1. Analysis of modern condition of international tourism.

2. Learn of the basic trends formation of tourist flows between Ukraine and Slovak Republic.

3. Learn of factors what affect on development international tourist contact.

4. Estimate tourist flows with help of mathematics exponent and structural analysis.

5. Describe geographical configuration, form tourist flows between Ukraine and Slovak Republic.

6. Determination of factors, which brake tourist flows between two countries. 
Problems of development tourist exchange between Ukraine and Slovak Republic discover Ukrainian scientist in different aspect. Main district and structure of tourist flows from Ukraine to another country and their regions are coverage in publications M. Malska, I. Chernin. Establishment cross-border cooperation between Ukraine and Slovak Republic dedicate to published V. Almashiy.

\section{The main problems}

Modern international tourism as priority direction of development social sphere accepted divided on two form: incoming or foreign, outgoing or foreign. They are different direct of tourist flows. One the same tourist flows between two countries for one country will determined as outgoing and for another - how incoming.

Under tourist flows understood direction of movement some number of tourist by some period of time. Main statistics indicators, which characterized tourist flows is amount of income, tourism revenue and costs, also length of stay. Most important statistical indicators, which characterize tourist flows of Ukraine, is amount of inhabitants, which visit another country with tourist aim, and number of tourist - citizen another country, which arrived to Ukraine. Due to the fact that administration of State border office of Ukraine in this rate include transit visitors, which VTO don't classification of tourist, determinate part or tourist from another country in common amount arrived to Ukraine very hard, it is possible only to look out general dynamic (Graph 1).

Graph 1: Number of tourist exchange between Ukraine and Slovakia (Tourist Group, 2014)

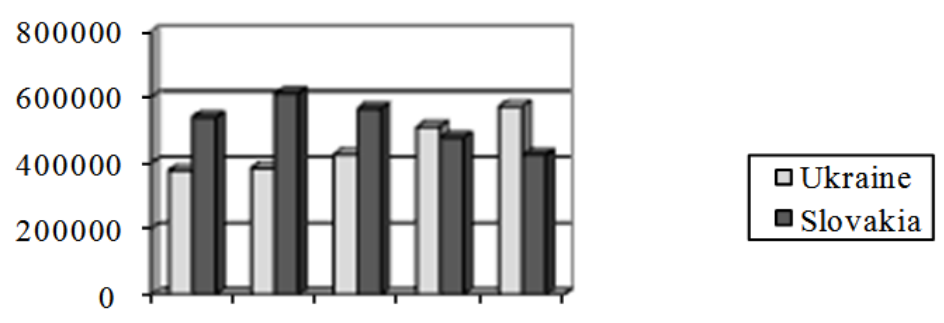

20092010201120122013

For the characteristics of tourist flows is important both quantitatively and qualitative indicators that reflect the features of tourist flows and their socioeconomic importance for the development of tourism in the region. These indicators should include the characteristics of tourist traffic: 
1) the ratio between the number of arrivals of foreign tourists from a given country and the number of people who went to the same country for tourism proposes;

2) such relevant categories of tourists in the total international tourists in the region;

3) main socio-economic trends relevant international tourist flows. One such indicator is the ratio of tourist exchanges. Where $\mathrm{Ni}$ - part of foreigners and of the first countries that visited the region (country) for tourism, the total number of foreign tourists; $\mathrm{Zi} \mathrm{-} \mathrm{the} \mathrm{proportion} \mathrm{of}$ citizens who visited the I -th country for tourism in the total number of foreign tourists in the region (country).

Significant of this index range is from -1 to +1 . Mining of the index indicates the dominance of tourists travelling on the arrival of foreigners. This state of international tourism in the region promotes its own tourist complex, as established tourism product is not consumed. If the sense is close to 0 , it means that the intensity of arrivals and the second country commensurate with the intensity of travelling in these countries. The positive coefficient tourist exchanges indicate the predominance of the arrival of foreigners leaving the citizens of Ukraine abroad. The situation in the region is the most attractive, because consumption contributes to the intensification created this tourist product and improvement of the efficiency of the local tourism industry. The extreme sense of the coefficient becomes a limited number of cases.

The coefficient of travelling between Ukraine and Slovakia was positive for Slovakia recently, due to successful tourism development strategy of the Slovak Republic (Graph 2).

Ukraine-Slovak travelling have different kinds of interesting peculiarity, which will be explain gradually.

The first factor of cooperation between Ukraine and Slovakia is historical preface - Slovak-Ukrainian connection have ancient traditions. Thought Slovakia from ancient time pass main trading road, which connected Ukraine with Western and Southern Europe. From Middle ages Ukraine visited Slovaks travelling: trades and craftsman. Main part of priesthood of Transkarpasian, from what later exist bishops or professors Bogoslovskiy school, studied in 18 century in Tarnavska Bogoslovskiy seminary. In Tarnava was print the first book for Transkarpasian Ukrainians: "Katehuzm” (1698), ”Bykvar" (1699) and "Kratcoe prupadkov moral sobranie" (1727).

First describes travel to Ukraine did Slovak, protestant confessor Daniel Krman, which in 1708-1709 years on order Semuhorodskoho prince witch visited here Swedish king Karla XII and meet with I. Mazepa. While their travelled in Slovak was Ukrainian philosophy- H. Skovoroda.

The first Slovak scientist who started deeper interest Ukraine, were Yan Kollar (1793-1852) and Pavel Hafaruk (1795-1861): there direct support contact 
with Ukrainian figures and had a positive impact the development of national renascence in Ukraine. Hafaruk one of the first in Europe defended identity of Ukrainian nation, their language and culture. In 40-th century 19 ct. Ukrainian poetry started learn L. Shur.

Graph 2: The coefficient of tourist exchanges between Ukraine and Slovakia in 2009 - 2013 (calculated by the author based on data from the State Border Service in Ukraine)

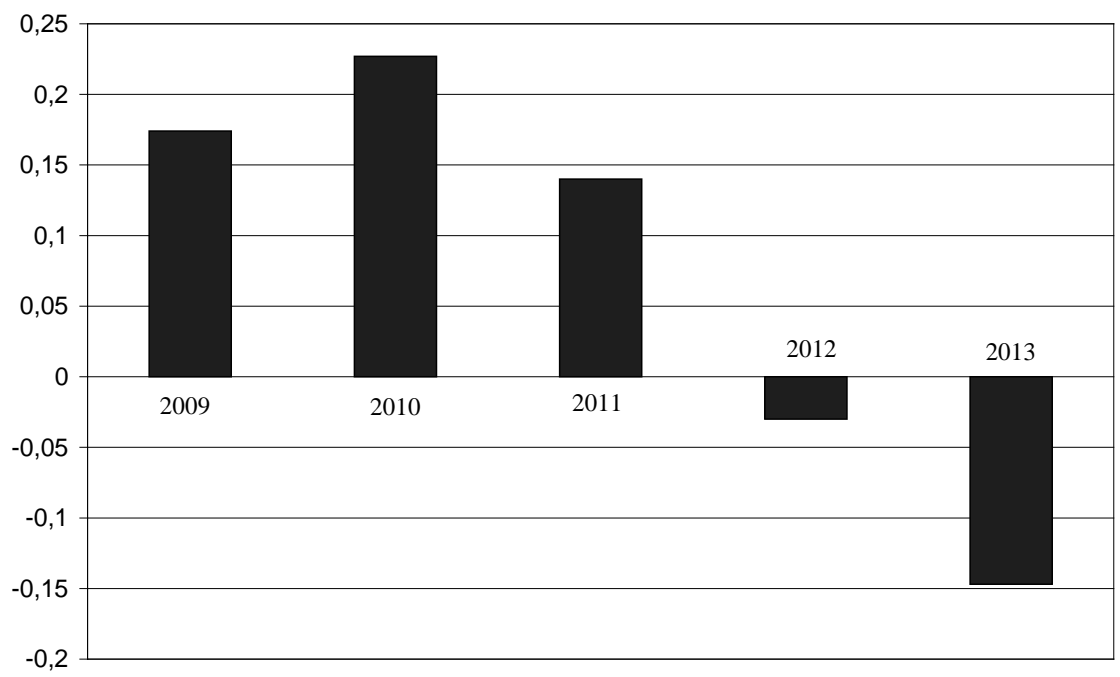

The main representative Ukrainian-Slovak relations in 19 ct. was Bogysh Nosak-Nezabydov (1818-1877); his own the first translate Slovak from Ukrainian language, posted in press ("Dyma pro vtechy dwoh brativ z Azova", 1848).

Another factor in the development of close cooperation in tourism between Ukraine and Slovakia are geographic and ethnic closeness. Ukrainians and Slovaks have joint border, length of which is about $100 \mathrm{~km}$ on the territory of the Priashiv Region, the centre of which is Priashiv. Its became the centre of Ukrainian culture in Slovakia. Due to geographical proximity, Slovaks are ethnically related to Ukrainian: both nations have a similar social structure, way of life, language and folklore, finally they were united by a joint misfortune until 1918 during Hungarian oppression. Nevertheless, their relationship was limited by Transcarpathia and less by Galicia.

Third, but not least important factor for developing tourist exchanges between the two countries is the presence of a transport system that would provide transport for travelling to tourist places. 
Railway transport provides transportation of goods and passengers by rail routes. It plays an important role in the economic relations between producers and consumers, districts and regions of the country and with foreign partners. Transportation at a distance of $300 \mathrm{~km}$ is effective. Double-track electrified railway lines connect our country since the days of the Soviet Union, as they supplied Ukrainian ore to Slovak at the plant in Koshitse.

Car Complex is a combination of vehicles without rails, equipment and facilities. Road Transport Infrastructure by quantitative indicators dominates among all kinds of transport. In terms of passenger traffic road transport in 5-6 times dominated by railway transport. Slovakia and Ukraine are connected by international trunk highway M-17, which corresponds to the latitudinal direction and extends from Kyiv through the cities of Western Ukraine - Rivne - Lviv to BCP Uzhgorod and BCP Chop.

However, besides the train, bus or car, you can use a faster mode of transport - plane. From Kyiv and Lviv are scheduled flights to Bratislava, and to Poprad - the centre of the ski resort - are charter flights from Kyiv.

A special elements of border infrastructure are border crossing points (BCPs). History of a Ukrainian-Slovak BCPs starts in 1993, when Slovakia became independent. Since that time it was not opened any additional BCP between Ukraine and Slovakia, although with other countries, such as Poland, the situation is much better.

At various meetings of international level government representatives and deputies of the Ukrainian-Slovak parties discuss the feasibility of the construction and opening of new border checkpoints, which will avoid red tape at the border crossing. In this context, the parties seek to discover and develop tourist border crossing point "Yluch - Zabrod", which will allow the development of local border traffic and it is especially important for the inhabitants of these regions. And on the other side it will reduce the waiting time at the already existing border crossing points that will have a positive impact on trade and other economic indicators. In the future, it would help to realize the project "Carpathian tourist road" and through activation of the tourism activity on the joint border area of "Carpathian Euroregion" (Almashiy, 2013).

Slovakia is attractive for tourists because of its beautiful nature, especially mountains, caves, cultural and historical monuments as medieval castles and towns, folk architecture, spas and ski lodges. The country has a high concentration of castles per one person. To favourite hotspots for tourists belongs capital and the High Tatras and Poprad. Also, travellers visit other mountain regions: the Low Tatras with bases Yasna, Hopok, Donovaly, National Park "Slovak Paradise", under the mountain regions Liptov with thermal water parks and pond "Lyptovska Mara" in Besheniova and city Spush where is famous castle and Levocha, This historical centre is included in the UNESCO list. Middle-aged cities with old historical centre is Bardiyiv, Kezhmarok, Banska Shtiavnutsia, Banska Bystrytsia, 
Kremnutsia, Trnava. Besides Bratuslava Castle also is known Zvolenskiy castle, Krasna Hvorka, Chahtytskiy castle and Trenchunskiy castle. From spa resorts foreign tourists visit especially Pieshtiany, Trenchianski Tieplitse, Rayetske Tieplytse, Bardeyovske Kypele. The flows of tourists from Ukraine to Slovakia resently increased (Graph 3).

Graph 3: Ukrainian tourists were serviced Slovak tourism organizations in 2009 2013 (Slovenská agentúra pre cestovný ruch, 2014)

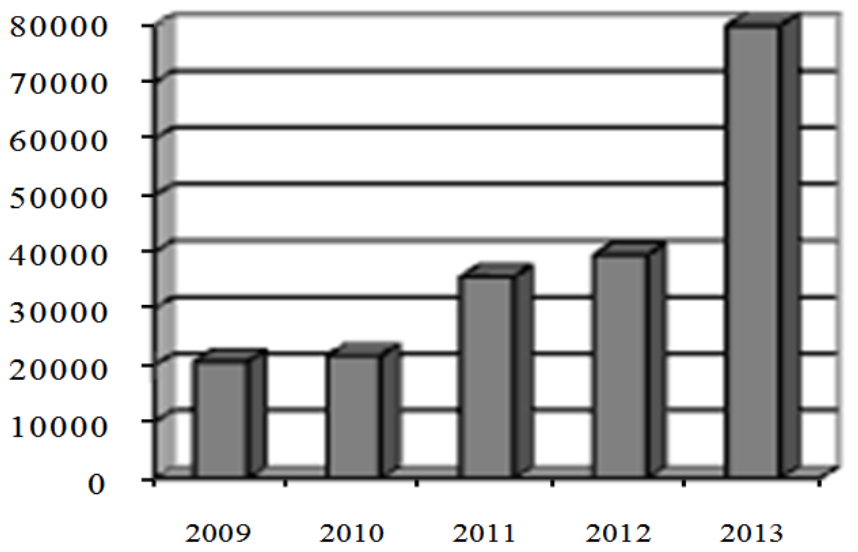

Most of the tourists who registered for nights in the country are themselves citizens of the Slovak Republic (59.1\%), the rest comes to rest from the Czech Republic (approx. 13.4\%), Poland (4.8\%) and Germany (3.7\%), Austria (1.7\%), Hungary (1.7\%) and Ukraine (5\%) (Slovenská agentúra pre cestovný ruch, 2014).

The country is represents in tourism by the Slovak Tourism Agency (slov. Slovenská agentúra pre cestovný ruch), which is engaged of the promotion of Slovakia abroad (Slovenská agentúra pre cestovný ruch, 2014).

Slovakia is aimed at inexpensive family vacation. Ski resorts is very popular among foreigners, including Ukrainian. When compared with Austria, the Slovak resorts are much cheaper, but the appeal of the Alps, in fact, is much higher and there are better service, and because of it in Austria is higher prices. The price policy of all resorts in Slovakia is very democratic. For example, accommodation with breakfast at the hotel "Druzhba" in the Low Tatras cost per day on average 45 euros. Meals can cost 10 euros.

As for hotel in Slovakia, they are here on a different flavour and wallet. However, even in tree star hotel to you propose Wellness-complex spa-procedure, internet, and other modern services. Besides as we was reported in the management of tourism Slovakia, they "will not have beds without infrastructure". It building 
hotel complex, then the investor has necessarily has take care of extensions the slopes, equipment them with snow guns, don't forget also about the culturalentertainment places, mode infrastructure etc. And in the off-season hotel were not empty, Slovaks active organize on their territory different business tour: seminars, conference, investment forums and festivals (Turisti opät' objavili Slovensko, 2014).

Ukraine tourists analysis over the past five years has shown a very insignificant part of Slovaks. Having all the prospects for development, our travel products are poorly advertised at the Slovak market. The most important tourist resources of Ukraine, which could attract Slovaks are:

Carpathian Mountains are considered one of the most popular resorts and tourist centres of the country. An original nature of territory, beauty of its Alpine meadows and woods, rough rivers and mountain lakes, soft climate, curative mineral sources, the historical and architectural monuments can attract everyone to themselves. Thousands of tourists and people who like travels and adventures come here. The Ukrainian Carpathians are relatively gentle peaks that rise as high as $2061 \mathrm{~m}$ (Mt. Hoverla). The largest resorts are located in Slavsko, Bukovel, Tysovets, and Dragobrat. Some of the smaller resorts are in Krasiya, Dolyna, Beskid, Polyana, Synevir, Yaremche, Verkhovnya, Kosiv, and Yavoriv. There are a number of Ukrainian ski resorts: Dragobrat, Bukovel, Pylypec, Izky, available for Slovak skiers.

Mineral water is among the main natural resources of Ukraine, good for drinking and cure of various internal organs diseases. The world-famous mineral waters of Truskavets, Morshin, Nemyriv and Shklo, which healing properties are comparable with widely known Baden-Baden and Karlovy Vary ones.

Kyiv (also known as Kiev), a scenic city of close to 3 million people situated on the Dnieper River, is the bustling capital of Ukraine. Ancient Kievan Rus, which reached its greatest period of ascendancy during the 11th and 12th centuries, was a centre of trade routes between the Baltic and the Mediterranean. The art and architecture of Kyiv are world treasures. The Cathedral of St. Sophia, where the princes of Kyiv were crowned in the years of Kyiv's grandeur, has outstanding mosaics and frescoes dating back to the 11th century. Overlooking the old section of Kyiv, Podol, stands the Ukrainian Baroque church of St. Andrew, much beloved by Ukrainians. The Percherska Lavra, the Monastery of the Caves, a short trolley ride from the center of town, has two 11th-century cathedrals on its grounds, in addition to its world-famous catacombs, bell tower, and museum collections. Close to the centre of town stands the Golden Gate, a structure which dates back to 1037. This recently reconstructed remains of the former fortified wall of the city defined the limits of the city in centuries past. Several blocks away, stands the magnificent 19th-century Cathedral of St. Volodymyr.

Kamyanets-Podilsky, one of the oldest cities in Ukraine, is considered a phenomenon of great cultural importance. A rocky island skirted by the tight loop 
of the Smotrich River flowing in a picturesque canyon, served as a unique pedestal on which over more than a thousand years both well-known and anonymous masters created a miracle in stone. Kamyanets-Podilsky is striking for the harmonious blend of landscape and architecture. The Old City's past is full of mystery. The precise age of Kamyanets-Podilsky has not until recently been ascertained. Some historians claimed that the city was founded at the beginning of our era by the Dacians during the Roman-Dacian wars. Allegedly, it was named Petridava or Klepidava (from the Greek "petra" or the Latin "lapis" meaning "stone" and the Dacian "dava" meaning "city").

The beautiful medieval city of Lviv has been the "Western Ukraine capital of culture" for three centuries. Founded in 1256 by Danylo Halytskiy, a prince of the Galicia-Volhynia principality, this city of 850,000 is only 50 kilometers from the Polish border. Under the long reign of Danylo's son, Lev (1264-1301), Lviv came to be the capital city of the Galician-Volhynian Kingdom. It is full of culture \& historical significance to Ukrainian history. One can find in Lviv the most beautiful architecture in Eastern Europe and it is no wonder that many who visit the city leave with lasting memories and love for Ukraine. So it is no wonder that the central part of the city is included in the UNESCO list of World Heritage.

\section{Conclusion}

Ukraine have all variety of tourist resources but tourist infrastructure was very low quality. The exceptions are the tourism industry in large cities Lviv, Kyiv, Kamyanets-Podilsky and ski resorts in the Carpathians. However, there is difficult arrival to this place. Only the main roads Ukraine is well equipped tourist infrastructure, while others discourage tourists with its bad providing. There is no information to ensure the development and promotion of Ukrainian tourism in the international tourism market.

At the same time, Slovakia tourism demonstrates more advantages in the international tourism market including information and advertising, Ukraine has to cooperate and learn from Slovakia.

\section{References}

ALMASHIY, V. 2013. Ukrainian and Slovakian interstate cooperation. Collection of scientific works: Efficacy public administration. 2013. Issue 35, p.65-72.

BORDUN, O. - KADNICHANCKIY, D. 2012. The analysis of tourist flow from Italy to Ukraine. Scientific journal of the Taras Shevchenko National University of Kiev. Series geogr., 2012, Issue 20, p. 157-165.

BORDUN, O. 2013. The analysis of international tourist flow Ukraine. Scientific journal of the Lviv University. Series geogr. 2013. Issue 43. Pt.2, p.137-146. 
SLOVENSKÁ AGENTÚRA PRE CESTOVNÝ RUCH (SACR). TOP 15 krajín podla počtu ubytovaných hostí na Slovensku za obdobie 2009 - 2012 [online]. http://www.sacr.sk [cit. 2014.09.26]

TOURIST GROUP. [on line]. http://www.ukrstat.gov.ua/ [cit. 2014.09.26]

TURISTI OPÄŤ OBJAVILI SLOVENSKO. [on line]. http://cestovanie.sme.sk/ c/6371299/turisti-opat-objavili-slovensko.html [cit. 2014.09.26]

Oresta Bordun, PhD., Associate professor

Department of Tourism, Faculty of Geography

Ivan Franko National University of Lviv

St. Doroshenko 41, 79000, Lviv

E-mail: obordun@ukr.net 